CLINICAL STUDY

\title{
Vitamin D increases circulating IGF1 in adults: potential implication for the treatment of GH deficiency
}

\author{
Pietro Ameri, Andrea Giusti ${ }^{1}$, Mara Boschetti ${ }^{2}$, Marta Bovio, Claudia Teti ${ }^{2}$, Giovanna Leoncini, Diego Ferone ${ }^{2}$, \\ Giovanni Murialdo and Francesco Minuto ${ }^{2}$ \\ Internal Medicine Unit, Department of Internal Medicine, Centre of Excellence for Biomedical Research, IRCCS-AOU San Martino-IST, University of \\ Genova, Viale Benedetto XV, 6, 16132 Genova, Italy, ${ }^{1}$ Department of Geriatrics and Muscoloskeletal Sciences, E.O. Galliera Hospital, Genova, Italy and \\ ${ }^{2}$ Endocrinology Unit, Department of Internal Medicine, Centre of Excellence for Biomedical Research, IRCCS-AOU San Martino-IST, University of Genova, \\ Viale Benedetto XV, 6, 16132 Genova, Italy
}

(Correspondence should be addressed to P Ameri; Email: pietroameri@unige.it)

\begin{abstract}
Objectives: Previous studies suggested that vitamin D modulates circulating IGF1. We investigated this effect in adults and its clinical relevance in the management of GH deficiency (GHD).

Design and methods: IGF1 levels were prospectively measured before and after 12 weeks of treatment with oral vitamin $\mathrm{D}_{3}$ (5000 or $7000 \mathrm{IU} /$ week) vs no intervention in 39 subjects $61.9 \pm 7.9$ years old. The frequency of IGF1 values $\geq 50$ th age- and sex-specific percentile in relation to vitamin $\mathrm{D}$ status, as determined by the concentration of 25-hydroxyvitamin $\mathrm{D}(25(\mathrm{OH}) \mathrm{D})$, was retrospectively assessed in 69 GHD patients $(57.4 \pm 16.6$ years) on stable hormone replacement and with $25(\mathrm{OH}) \mathrm{D}$ and IGF1 concurrently measured.

Results: Treatment with 5000 and $7000 \mathrm{IU}$ vitamin $\mathrm{D}_{3} /$ week significantly raised $25(\mathrm{OH}) \mathrm{D}$ by $12.7 \pm 8.4$ and $13.1 \pm 6.5 \mathrm{ng} / \mathrm{ml}$ respectively (both $P<0.001$ vs baseline). In the 7000 IU group, IGF1 levels also significantly increased by $31.3 \pm 36.7 \mathrm{ng} / \mathrm{ml}(P=0.01)$. Neither 25(OH)D nor IGF1 significantly varied in controls. IGF1 was $\geq 50$ th percentile more frequently in GHD patients with $25(\mathrm{OH}) \mathrm{D}$ levels $\geq 15$ than $<15 \mathrm{ng} / \mathrm{ml}$ (65.9 vs $40.0 \%, P<0.05)$. Logistic regression with adjustment for recombinant human $\mathrm{GH}$ (rhGH) dose, vitamin D supplements, gender, use of thyroid hormones, corticosteroids or estrogen/testosterone, and season revealed a significant positive association between $\geq 15 \mathrm{ng} / \mathrm{ml} 25(\mathrm{OH}) \mathrm{D}$ and IGF1 $\geq 5$ th percentile (OR 4.4, 95\% CI 1.0-18.8, P<0.05). A significant negative correlation between $25(\mathrm{OH}) \mathrm{D}$ concentrations and rhGH dose was found after correcting for age and IGF1 $(\beta-0.042, P<0.01)$, but not after further adjusting for sex, thyroid, adrenal or gonadal replacement, and season $(\beta-0.037, P=0.06)$.

Conclusions: Vitamin D increases circulating IGF1 in adults. As a result, a better vitamin D status may ease the achievement of normal IGF1 values in GHD.
\end{abstract}

European Journal of Endocrinology 169 767-772

\section{Introduction}

It has long been known that insulin-like growth factor 1 (IGF1) causes an increase in the circulating levels of 1,25-dihydroxyvitamin $\mathrm{D}\left(1,25(\mathrm{OH})_{2} \mathrm{D}\right)$, the hormonally active vitamin $\mathrm{D}$ metabolite, by stimulating the expression and activity of the 1 $\alpha$-hydoxylase that produces $1,25(\mathrm{OH})_{2} \mathrm{D}$ in the kidney $(1,2)$. Indeed, plasma $1,25(\mathrm{OH})_{2} \mathrm{D}$ is significantly higher in active than controlled acromegaly, with a tendency to hypercalcemia, hyperphosphatemia, and hypercalciuria (3). On the other hand, more recent data has suggested that vitamin D may contribute to determining IGF 1 concentrations. Mice knockout for the vitamin D receptor (VDR) exhibit 30\% lower IGF1 levels compared with WT animals (4) and a significant increase in serum IGF1 was noted in response to vitamin D in two small cohorts of children $(5,6)$. Furthermore, cross-sectional analyses of communitybased cohorts disclosed a positive correlation between the concentrations of 25-hydroxyvitamin D $(25(\mathrm{OH}) \mathrm{D})$, the marker of vitamin D status, and IGF1 $(7,8,9,10)$.

Here we first conducted an open-label, controlled study of the changes in circulating IGF1 following vitamin D supplementation in adults. Then, we asked whether the influence of vitamin D on IGF1 might be clinically relevant for the management of growth hormone deficiency (GHD), which relies on measurement of IGF1 levels. 


\section{Subjects and methods}

\section{Intervention study}

The effect of vitamin D on IGF1 concentrations was investigated in 39 asymptomatic outpatients, who were consecutively selected among those referred to an Internal Medicine Clinic for cardiovascular risk assessment because of one or more established risk factors among familial history, smoking, arterial hypertension, and hypercholesterolemia. The following inclusion criteria were applied: absence of acute or uncontrolled chronic diseases; normal dietary habits; no evidence of intestinal malabsorption or hepatic disease; glomerular filtration rate $>60 \mathrm{ml} / \mathrm{min}$ per $1.73 \mathrm{~m}^{2}$, as estimated by the MDRD equation; no use of medications known to affect vitamin D metabolism, nor of vitamin D supplements for the previous 6 months; and no evidence of pituitary disease. All subjects were Caucasian but one, who was Indian, and lived an active life, with variable time spent outdoors. The study was located in Genova, Italy (latitude $44^{\circ} \mathrm{N}$ ). It was approved by the Local Ethic Committee and performed in accordance to the guidelines in the Declaration of Helsinki. Participants gave their written informed consent.

During the same visit, patients were screened, recruited if eligible, and randomized to treatment with oral vitamin $\mathrm{D}_{3}$ (Abiogen Pharma, Pisa, Italy) or no intervention. Since we had preliminarily observed a comparable 25(OH)D increment in response to 5000 and $7000 \mathrm{IU}$ vitamin $\mathrm{D}_{3}$ once a week (11), we tested these two doses to determine whether they would also affect IGF1 levels in a similar way. All subjects were instructed not to take any additional vitamin D and left on a free diet. Nineteen participants were studied between June and November and another 20 between December and May, when 25(OH)D concentrations are highest and lowest, respectively, in northern Italian outpatients (12). During each time period, one out of every three participants was assigned to $5000 \mathrm{IU}$ vitamin $\mathrm{D}_{3}$, another one to no treatment, and the last one to 7000 IU vitamin $\mathrm{D}_{3}$.

Total 25(OH)D, 1,25(OH $)_{2} \mathrm{D}$, and IGF1 were measured on fasted serum samples collected at baseline and 12 weeks later. Serum 25(OH)D was assayed by chemiluminescent immunoassay on the DiaSorin Liaison System (DiaSorin, Saluggia, Italy) (13); within-assay and between-assay variability (coefficients of variation $(\mathrm{CV})$ ) were $2.9-5.5$ and $6.9-12.7 \%$ respectively. Concentrations of IGF1 were determined by RIA (DIAsource ImmunoAssays, Nivelles, Belgium) after acid ethanol extraction, as previously described (14); within-assay and between-assay CV were 1.7-9.1 and $4.1-9.0 \%$ respectively. Serum $1,25(\mathrm{OH})_{2} \mathrm{D}$ was measured by RIA (Immunodiagnostic System, Tyne and Wear, UK), within-assay and total CV being 8.6-16.6 and $11.9-20 \%$ respectively. Pre- and post-samples from the same individual were run in the same assay.
Creatinine, calcium, and phosphate levels were also assessed by automated assay in the central laboratory of the hospital where the study was performed.

\section{Retrospective analysis}

Data were obtained by reviewing the medical records of adult GHD patients followed by a tertiary center in Genova, who i) were on stable treatment with recombinant human $\mathrm{GH}(\mathrm{rhGH})$ and other hormones if indicated and ii) had undergone measurement of $25(\mathrm{OH}) \mathrm{D}$ and IGF1 concentrations on the same occasion. The following information was retrieved: weekly dose of rhGH (mg) and, if any, of vitamin D (IU) at the time of biochemical assessment; season of the year when 25(OH)D and IGF1 had been assessed (June-November or December-May); and use or not of thyroid hormones, corticosteroids, or estrogen/testosterone. To account for the possibility that some young women were sufficiently estrogenized despite not being on gonadal replacement therapy, gonadal hormone status of female patients was also categorized by dividing them into those older than 50 years (considered as menopausal or post-menopausal) and not given estrogen vs those younger than 50 years or on estrogen regardless of their age.

\section{Statistical analysis}

Categorical data are presented as relative and absolute frequencies and continuous variables as mean \pm s.D. or median (interquartile range), depending on the distribution. Comparisons were drawn by $\chi^{2}$-, $t$-test, MannWhitney $U$ test, and one-way ANOVA, as appropriate. To correct for the differences in female:male ratio and BMI among the three groups of the intervention study, the 12-week changes in 25(OH)D and IGF1 were compared by analysis of covariance with adjustment for gender and BMI.

For each GHD case, we assessed whether serum IGF1 was at least equal to the 50th percentile for age and gender, based on reference values for the Italian population (14). The percentage of patients with IGF1 $\geq 50$ th percentile was then examined across different vitamin D categories, defined as follows: i) $<15$ vs $\geq 15 \mathrm{ng} / \mathrm{ml} 25(\mathrm{OH}) \mathrm{D}$, since the positive association between $25(\mathrm{OH}) \mathrm{D}$ and IGF1 was reported to be present only when $25(\mathrm{OH}) \mathrm{D}$ concentrations were above $15 \mathrm{ng} / \mathrm{ml}(7)$; ii) $<10 \mathrm{ng} / \mathrm{ml} 25(\mathrm{OH}) \mathrm{D}$, which identifies severe vitamin D deficiency, $\geq 20 \mathrm{ng} / \mathrm{ml} 25(\mathrm{OH}) \mathrm{D}$, which meets the requirements of most individuals according to a recent position statement of the Institute of Medicine (15), and the intermediate class $\geq 10 \mathrm{ng} / \mathrm{ml}$ but $<20 \mathrm{ng} / \mathrm{ml} 25(\mathrm{OH}) \mathrm{D}$; and (iii) $<30 \mathrm{vs} \geq 30 \mathrm{ng} / \mathrm{ml}$ $25(\mathrm{OH}) \mathrm{D}$, which identify vitamin D deficiency/insufficiency and sufficiency, respectively, according to the Endocrine Society (16). These cutoffs were also entered as independent variables into logistic and linear 
regression models in which IGF1 levels and rhGH dose were the outcomes. Statistical significance was set at $P<0.05$. Analyses were performed with Statview version 5.0.1 for Windows (SAS Institute, Inc., Cary, $\mathrm{NC}$, USA).

\section{Results}

\section{Increase in circulating IGF1 following vitamin $\mathrm{D}_{3}$ treatment}

Baseline characteristics were similar between the intervention study groups, except for BMI, which was significantly higher in subjects allocated to $7000 \mathrm{IU}$ vitamin $\mathrm{D}_{3}$ /week than in those given no supplementation (Table 1). Mean $25(\mathrm{OH}) \mathrm{D}$ was nonsignificantly higher in untreated than treated patients and the prevalence of vitamin D deficiency, as defined by

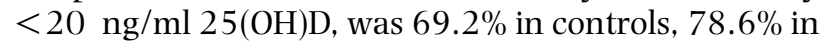
the 5000 IU group, and $83.3 \%$ in the 7000 IU one (NS). Serum IGF1 was nonsignificantly lower in subjects receiving $7000 \mathrm{IU}$ vitamin $\mathrm{D}_{3}$ /week than in the others (Table 1). Ongoing chronic therapies included antihypertensive drugs and statins, with no significant differences among the three groups (data not shown).
Vitamin $\mathrm{D}_{3}$ supplementation significantly raised $25(\mathrm{OH}) \mathrm{D}$ levels over 12 weeks, with the values achieved using 5000 or $7000 \mathrm{IU} /$ week being very similar (Table 1). Supplementation with 7000 IU/week but not 5000 IU/week, also significantly increased circulating IGF1. No significant variation in the concentrations of $1,25(\mathrm{OH})_{2} \mathrm{D}$ was observed in treated patients, nor of $25(\mathrm{OH}) \mathrm{D}, 1,25(\mathrm{OH})_{2} \mathrm{D}$, and IGF1 in controls (Table 1). The 12-week changes in $25(\mathrm{OH}) \mathrm{D}$ and IGF1 levels remained significantly different among the study groups after correcting for gender and BMI (Table 1).

\section{Positive association of vitamin D status with circulating IGFI in GHD}

Sixty-nine GHD patients $(57.4 \pm 16.6$ years old, 33 women) were on stable rhGH replacement therapy (mean dose $2.2 \pm 1.4 \mathrm{mg} /$ week) and had undergone measurement of $25(\mathrm{OH}) \mathrm{D}$ and IGF1 at the same time. Most had postsurgical hypopituitarism and none had clinical or biochemical signs of malnutrition. The percentage of subjects with serum IGF1 $\geq 50$ th ageand sex-specific percentile nonsignificantly increased across the $25(\mathrm{OH}) \mathrm{D}$ categories $<10 \mathrm{ng} / \mathrm{ml}$, between 10 and $20 \mathrm{ng} / \mathrm{ml}$, and $\geq 20 \mathrm{ng} / \mathrm{ml}(50,57.1$, and $60 \%$

Table 1 Patients' characteristics at baseline and after 12 weeks of treatment with vitamin $D_{3}$ vs no intervention. Data are presented as mean \pm s.D. unless otherwise indicated.

\begin{tabular}{|c|c|c|c|c|}
\hline & No treatment & 5000 IU D $D_{3} /$ week & 7000 IU $D_{3} /$ week & $P$ for trend \\
\hline$n$ & 13 & 14 & 12 & \\
\hline June-November & 6 & 7 & 6 & \\
\hline December-May & 7 & 7 & 6 & 0.61 \\
\hline Women $(n, \%)$ & $9(69.2)$ & $11(78.6)$ & $7(58.3)$ & 0.76 \\
\hline Age (years) & $61.9 \pm 7.5$ & $62.7 \pm 6.4$ & $61.1 \pm 10.2$ & 0.99 \\
\hline $\mathrm{BMI}\left(\mathrm{kg} / \mathrm{m}^{2}\right)$ & $25.9 \pm 5.4$ & $29.6 \pm 4.1$ & $32.1 \pm 6.1^{\mathrm{a}}$ & 0.02 \\
\hline eGFR $\left(\mathrm{ml} / \mathrm{min}\right.$ per $\left.1.73 \mathrm{~m}^{2}\right)$ & $77 \pm 10.7$ & $82.5 \pm 18.4$ & $83.4 \pm 11.9$ & 0.48 \\
\hline \multicolumn{5}{|l|}{ Serum creatinine (mg/dl) } \\
\hline Baseline & $0.8 \pm 0.1$ & $0.8 \pm 0.2$ & $0.8 \pm 0.1$ & 0.70 \\
\hline 12 weeks & $0.8 \pm 0.1$ & $0.8 \pm 0.1$ & $0.8 \pm 0.2$ & 0.75 \\
\hline \multicolumn{5}{|l|}{ Serum calcium (mg/dl) } \\
\hline Baseline & $9.4 \pm 0.7$ & $9.5 \pm 0.4$ & $9.4 \pm 0.7$ & 0.90 \\
\hline 12 weeks & $9.2 \pm 0.7$ & $9.6 \pm 0.4$ & $9.6 \pm 0.6$ & 0.16 \\
\hline \multicolumn{5}{|l|}{ Serum phosphate $(\mathrm{mg} / \mathrm{dl})$} \\
\hline Baseline & $3.2 \pm 0.7$ & $3.2 \pm 0.5$ & $3.0 \pm 0.4$ & 0.50 \\
\hline 12 weeks & $3.2+0.6$ & $3.4+0.6$ & $2.8+0.6$ & 0.11 \\
\hline \multicolumn{5}{|l|}{ Serum 25(OH)D (ng/ml) } \\
\hline Baseline & $16 \pm 8.8$ & $14.3 \pm 6.5$ & $12.2 \pm 6.6$ & 0.44 \\
\hline 12 weeks & $19.5 \pm 10$ & $27 \pm 10.4^{\dagger}$ & $25.3 \pm 7.9^{\dagger}$ & 0.12 \\
\hline 12-week change & $3.6 \pm 7.3$ & $12.7 \pm 8.4$ & $13.1 \pm 6.5^{\mathrm{b}}$ & 0.008 \\
\hline \multicolumn{5}{|l|}{ Serum $1,25(\mathrm{OH})_{2} \mathrm{D}(\mathrm{ng} / \mathrm{ml})$} \\
\hline Baseline & $92 \pm 34.5$ & $77.8 \pm 25.5$ & $92.1 \pm 38.8$ & 0.47 \\
\hline 12 weeks & $85.3+30$ & $92.4+34.4$ & $104.6+36.7$ & 0.55 \\
\hline 12-week change & $-5.3 \pm 30.5$ & $13.5 \pm 16.6$ & $12.6 \pm 30.8$ & 0.48 \\
\hline \multicolumn{5}{|l|}{ Serum IGF1 (ng/ml) } \\
\hline Baseline & $183.9 \pm 59$ & $184.5 \pm 79.1$ & $157.5 \pm 39.8$ & 0.47 \\
\hline 12 weeks & $173.3 \pm 60.7$ & $188.7 \pm 83.1$ & $188.8 \pm 60.3^{*}$ & 0.81 \\
\hline 12-week change & $-10.6 \pm 17.8$ & $4.15 \pm 26.1$ & $31.3 \pm 36.7^{c}$ & 0.007 \\
\hline
\end{tabular}

eGFR, estimated glomerular filtration rate. ${ }^{\star} P=0.01$ vs baseline and ${ }^{\dagger} P<0.001$ vs baseline.

aFisher's post-hoc test, $P<0.05$ for $7000 \mathrm{IU}$ vitamin $\mathrm{D}_{3}$ /week vs no treatment.

${ }^{\text {b} F i s h e r ' s ~ p o s t-h o c ~ t e s t, ~} P<0.01$ for both 5000 and $7000 \mathrm{IU} /$ week vs no treatment.

'Fisher's post-hoc test, $P<0.01$ for $7000 \mathrm{IU} /$ week vs both no treatment and $5000 \mathrm{IU} /$ week. 
Table 2 Characteristics of patients with GHD as divided by the $15 \mathrm{ng} / \mathrm{ml} 25(\mathrm{OH}) \mathrm{D}$ cutoff. Age and BMl are given as mean \pm s.D., rhGH dose as median with interquartile range; categorical variables are presented as absolute and relative frequencies.

\begin{tabular}{lccc}
\hline & \multicolumn{2}{c}{ 25(OH)D } & \\
\cline { 2 - 3 } & $<15 \mathrm{ng} / \mathrm{ml}$ & $\geq 15 \mathrm{ng} / \mathrm{ml}$ & $\boldsymbol{P}$ \\
\hline$n$ & 25 & 44 & \\
Age (years) & $54 \pm 17$ & $59.3 \pm 16.2$ & 0.21 \\
Women $(n, \%)$ & $15(60)$ & $18(40.9)$ & \\
$\begin{array}{l}\text { Menopausal/post- } \\
\quad \text { menopausal and }\end{array}$ & $9(60)$ & $15(83.3)$ & 0.27 \\
$\quad$ not on ERT & & & \\
BMI (kg/m ${ }^{2}$ ) & $29.6 \pm 5.6$ & $29.5 \pm 6.2$ & 0.96 \\
$\begin{array}{l}\text { Patients with serum IGF1 } \\
\quad \geq 50 \text { th percentile }(n, \%)\end{array}$ & $10(40)$ & $29(65.9)$ & 0.04 \\
rhGH dose (mg/week) & $2.4(1.3-2.7)$ & $1.8(1.2-2.4)$ & 0.20 \\
\hline
\end{tabular}

ERT, estrogen replacement therapy.

respectively). Only six cases $(8.7 \%)$ had $\geq 30 \mathrm{ng} / \mathrm{ml}$ $25(\mathrm{OH}) \mathrm{D}$, and IGF1 values were $\geq 5$ oth percentile in three of them. In contrast, IGF1 levels $\geq 50$ th percentile were significantly more frequent in patients with $\geq 15 \mathrm{ng} / \mathrm{ml} 25(\mathrm{OH}) \mathrm{D}$ than in those with $<15 \mathrm{ng} / \mathrm{ml}$ $25(\mathrm{OH}) \mathrm{D}$ (Table 2). In logistic regression accounting for rhGH dose and use of vitamin D supplements, $25(\mathrm{OH}) \mathrm{D}$ concentrations $\geq 15 \mathrm{ng} / \mathrm{ml}$ were significantly associated with IGF1 levels $\geq 50$ th percentile (OR 3.5, 95\% CI $1.1-10.6, P<0.05)$. This result was not substantially changed by further adjustment for gender, use of thyroid hormones, corticosteroids or estrogen/testosterone, and season (OR 4.4, 95\% CI 1.0-18.8, P<0.05), nor was it modified when gonadal hormone status was taken into account instead of estrogen replacement in female patients (OR 4.6, 95\% CI 1.0-20.6, P<0.05). Since there was a trend for use of higher rhGH doses in cases with $<15 \mathrm{ng} / \mathrm{ml} 25(\mathrm{OH}) \mathrm{D}$ (Table 2), we studied the relationship between vitamin $\mathrm{D}$ status and weekly amount of rhGH. Linear regression with adjustment for age and IGF1 concentrations revealed a significant negative correlation between $25(\mathrm{OH}) \mathrm{D}$ levels and rhGH dose $(\beta-0.042, P<0.01)$. However, the strength of the association was attenuated to nonsignificance when gender, use of hormones, and season were corrected for $(\beta-0.037, P=0.06)$. No significant results were obtained when the other $25(\mathrm{OH}) \mathrm{D}$ cutoffs were substituted for the $15 \mathrm{ng} / \mathrm{ml}$ one in the regression models.

\section{Discussion}

This work consisted of two steps. First, we assessed the effects of vitamin D on circulating IGF1 in adults. Second, we explored the clinical impact of vitamin D modulation of IGF1 in GHD. To our knowledge, this latter issue has never been addressed before.

Concentrations of IGF1 were significantly higher following vitamin D supplementation in our sample.
Although the possibility of a type 1 error cannot be excluded given the small size of the treatment cohort, this finding is substantiated by previous studies in children with rickets, in which serum IGF1 also significantly increased after treatment with vitamin D $(5,6)$. Overall, these data indicate that vitamin D positively affects IGF1 levels. Consistent with these findings, circulating IGF1 is lower in $V d r^{-/-}$mice than in WTs (4). Moreover, a positive association between $25(\mathrm{OH}) \mathrm{D}$ and IGF1 values has been repeatedly found in healthy subjects $(7,8,9,10)$.

The present study did not investigate the mechanism by which vitamin D may influence the amount of IGF1 in the bloodstream, nor has it been done by others. Vitamin D is most likely to regulate IGF1 concentrations by acting in the liver, since this organ is the main source of circulating IGF1 (17). In addition, hepatic cells secrete IGFBP3 and acid-labile subunit, which carry IGF1 in the blood within a ternary complex (18). Interestingly, transgenic mice deficient in steroid receptor coactivator-3, a co-activator of the VDR, have reduced IGF1 levels because of a decrease in liver expression of the IGFBP 3 gene and thereby in serum IGFBP3, with ensuing enhanced clearance of IGF1 (19).

The effect of vitamin D on IGF1 appeared to be dose dependent in our patients. While the change in $25(\mathrm{OH}) \mathrm{D}$ induced by 5000 or $7000 \mathrm{IU}$ vitamin $\mathrm{D}_{3}$ /week was very similar, only the highest dosage significantly raised IGF1 concentrations. Variations in both $25(\mathrm{OH}) \mathrm{D}$ and IGF1 were not significant in controls. It must be acknowledged that the untreated, 5000 and 7000 IU groups were significantly different in terms of BMI. This is a major shortcoming of our work, likely due to the small size and highly heterogeneous composition of the study sample, which randomization could not correct for. The lack of a higher increase in $25(\mathrm{OH}) \mathrm{D}$ in the 7000 group was most probably due to their higher BMI, since excess adiposity dilutes supplemental vitamin D (20). The amount of adipose tissue is also known to affect GH and IGF1 and, although the analysis of the changes in IGF1 was not substantially modified by adjustment for BMI, residual confounding may still exist. However, the possibility of a dose-response relationship between vitamin D and IGF1 should be taken into consideration and specifically addressed by future studies with far more different vitamin $\mathrm{D}_{3}$ doses than those used here. Based on the evidence that hepatic cells i) not only hydroxylate vitamin $D$ to $25(\mathrm{OH}) \mathrm{D}$ but can also further convert $25(\mathrm{OH}) \mathrm{D}$ to $1,25(\mathrm{OH})_{2} \mathrm{D}(21)$ and ii) express the VDR (22), we hypothesize that oral vitamin $\mathrm{D}_{3}$ reaches the liver through the portal circulation, is sequentially converted to $25(\mathrm{OH}) \mathrm{D}$ and then $1,25(\mathrm{OH})_{2} \mathrm{D}$, and stimulates the synthesis of IGF1/IGFBP3 in a paracrine/autocrine fashion. The fat mass would not interfere with this intra-hepatic activity of vitamin $\mathrm{D}$, since it occurs before the passage into the systemic circulation which brings 
vitamin D to the adipose tissue. Clearly, this interpretation is purely speculative and must be verified.

The induction of IGF1 by vitamin D may be relevant for human health, since epidemiological studies showed a positive interaction between vitamin $\mathrm{D}$ intake or levels and circulating IGF1 in diminishing the risk of adverse outcomes, such as metabolic syndrome (8) or mammographic breast density (a surrogate of breast cancer risk) (23). On the other hand, excess IGF1 may contribute to the development of several types of tumors (24), which raises the possibility that the increase in serum IGF1 following vitamin D treatment may be detrimental in some cases.

Out of the research context, however, IGF1 concentrations in the blood are measured in selected cases, among which is GHD. Low IGF1 levels are partly responsible for the morbidity and mortality associated with GHD and normalization of IGF1 is one of the goals of treatment with rhGH $(25,26)$. Factors such as age, gender, and estrogen status are known to impact the hepatic synthesis of IGF1 in response to rhGH and it is recommended that $\mathrm{GH}$ dosing take them into account (26). We reasoned that knowing whether vitamin D status affects circulating IGF1 would be of practical importance for the endocrinologist managing GHD. In our series, cases with serum 25(OH)D equal to or higher than $15 \mathrm{ng} / \mathrm{ml}$ were over four times more likely to have IGF1 values at least at the 50th percentile for age and sex. Therefore, it can be speculated that a better vitamin D status may favor the normalization of IGF1 in adults with treated GHD. Specifically designed and adequately powered studies are required to confirm this hypothesis.

In conclusion, the present work confirms that vitamin D increases circulating IGF1, for the first time demonstrating this effect specifically in adults. More importantly, its puts the influence of vitamin D on IGF1 in a clinical perspective, showing it may be relevant for the management of GHD. The interactions between vitamin D and IGF1 are certainly worth further investigation.

\section{Declaration of interest}

A Giusti received lecture fees from Abiogen Pharma. D Ferone consults for Eli Lilly. The other authors have nothing to declare.

\section{Funding}

This research did not receive any specific grant from any funding agency in the public, commercial or not-for-profit sector.

\section{References}

1 Wei S, Tanaka H \& Seino Y. Local action of exogenous growth hormone and insulin-like growth factor-I on dihydroxyvitamin D production in LLC-PK1 cells. European Journal of Endocrinology 1998139 454-460. (doi:10.1530/eje.0.1390454)

2 Bianda T, Hussain MA, Glatz Y, Bouillon R, Froesch ER \& Schmid C. Effects of short-term insulin-like growth factor-I or growth hormone treatment on bone turnover, renal phosphate reabsorption and 1,25 dihydroxyvitamin D3 production in healthy man. Journal of Internal Medicine 1997241 143-150. (doi:10.1046/j.1365-2796.1997.94101000.x)

3 Kamenický P, Blanchard A, Gauci C, Salenave S, Letierce A, Lombès M, Brailly-Tabard S, Azizi M, Prié D, Souberbielle JC et al. Pathophysiology of renal calcium handling in acromegaly: what lies behind hypercalciuria? Journal of Clinical Endocrinology and Metabolism 201297 2124-2133. (doi:10.1210/jc.2011-3188)

4 Song Y, Kato S \& Fleet JC. Vitamin D receptor (VDR) knockout mice reveal VDR-independent regulation of intestinal calcium absorption and $\mathrm{ECaC} 2$ and calbindin D9k mRNA. Journal of Nutrition 2003133 374-380.

5 Bereket A, Cesur Y, Özkan B, Adal E, Turan S, Onan SH, Döneray H, Akçay T \& Haklar G. Circulating insulin-like growth factor binding protein-4 (IGFBP-4) is not regulated by parathyroid hormone and vitamin $\mathrm{D}$ in vivo: evidence from children with rickets. Journal of Clinical Research in Pediatric Endocrinology 20102 17-20. (doi:10.4274/jcrpe.v2i1.17)

6 Soliman AT, Al Khalaf F, Alhemaidi N, Al Ali M, Al Zyoud M, Yakoot K, Bereket A, Cesur Y, Özkan B, Adal E et al. Linear growth in relation to the circulating concentrations of insulin-like growth factor I, parathyroid hormone, and 25-hydroxy vitamin D in children with nutritional rickets before and after treatment: endocrine adaptation to vitamin D deficiency. Metabolism 2008 57 95-102. (doi:10.1016/j.metabol.2007.08.011)

7 Gómez JM, Maravall FJ, Gómez N, Navarro MA, Casamitjana R \& Soler J. Relationship between 25-(OH) D3, the IGF-I system, leptin, anthropometric and body composition variables in a healthy, randomly selected population. Hormone and Metabolic Research 200436 48-53. (doi:10.1055/s-2004-814103)

8 Hyppönen E, Boucher BJ, Berry DJ \& Power C. 25-Hydroxyvitamin D, IGF-1, and metabolic syndrome at 45 years of age: a cross-sectional study in the 1958 British Birth Cohort. Diabetes 200857 298-305. (doi:10.2337/db07-1122)

9 Forouhi NG, Luan J, Cooper A, Boucher BJ \& Wareham NJ. Baseline serum 25-hydroxy vitamin D is predictive of future glycemic status and insulin resistance: the Medical Research Council Ely Prospective Study 1990-2000. Diabetes 200857 2619-2625. (doi:10.2337/db08-0593)

10 Bogazzi F, Rossi G, Lombardi M, Tomisti L, Sardella C, Manetti L, Curzio O, Marcocci C, Grasso L, Gasperi M et al. Vitamin D status may contribute to serum insulin-like growth factor I concentrations in healthy subjects. Journal of Endocrinological Investigation 201134 e200-e203. (doi:10.3275/7228)

11 Ameri P, Bovio M \& Murialdo G. Treatment for vitamin D deficiency: here and there do not mean everywhere. European Journal of Nutrition 201251 257-259. (doi:10.1007/s00394012-0316-6)

12 Bettica P, Bevilacqua M, Vago T \& Norbiato G. High prevalence of hypovitaminosis D among free-living postmenopausal women referred to an osteoporosis outpatient clinic in northern Italy for initial screening. Osteoporosis International $19999226-229$. (doi:10.1007/s001980050141)

13 Wagner D, Hanwell HE \& Vieth R. An evaluation of automated methods for measurement of serum 25-hydroxyvitamin D. Clinical Biochemistry 200942 1549-1556. (doi:10.1016/j.clinbiochem. 2009.07.013)

14 Aimaretti G, Boschetti M, Corneli G, Gasco V, Valle D, Borsotti M, Rossi A, Barreca A, Fazzuoli L, Ferone D et al. Normal agedependent values of serum insulin growth factor-I: results from a healthy Italian population. Journal of Endocrinological Investigation 200831 445-449.

15 Ross AC, Manson JE, Abrams SA, Aloia JF, Brannon PM, Clinton SK, Durazo-Arvizu RA, Gallagher JC, Gallo RL, Jones G et al. The 2011 report on dietary reference intakes for calcium and vitamin D from the Institute of Medicine: what clinicians need to know. Journal of Clinical Endocrinology and Metabolism 201196 53-58. (doi:10.1210/jc.2010-2704)

16 Holick MF, Binkley NC, Bischoff-Ferrari HA, Gordon CM, Hanley DA, Heaney RP, Murad MH, Weaver CM \& Endocrine Society. Evaluation, treatment, and prevention of vitamin D 
deficiency: an Endocrine Society clinical practice guideline. Journal of Clinical Endocrinology and Metabolism 2011961911 1930. (doi:10.1210/jc.2011-0385)

17 Yakar S, Liu JL, Stannard B, Butler A, Accili D, Sauer B \& LeRoith D. Normal growth and development in the absence of hepatic insulin-like growth factor I. PNAS 199996 7324-7329. (doi:10.1073/pnas.96.13.7324)

18 Jones JI \& Clemmons DR. Insulin-like growth factors and their binding proteins: biological actions. Endocrine Reviews 199516 3-34. (doi:10.1210/edrv-16-1-3)

19 Liao L, Chen X, Wang S, Parlow AF \& Xu J. Steroid receptor coactivator 3 maintains circulating insulin-like growth factor I (IGF-I) by controlling IGF-binding protein 3 expression. Molecular and Cellular Biology 200828 2460-2469. (doi:10.1128/MCB.01163-07)

20 Drincic AT, Armas LA, Van Diest EE \& Heaney RP. Volumetric dilution, rather than sequestration best explains the low vitamin D status of obesity. Obesity 201220 1444-1448. (doi:10.1038/oby. 2011.404)

21 Gal-Tanamy M, Bachmetov L, Ravid A, Koren R, Erman A, Tur-Kaspa R \& Zemel R. Vitamin D: an innate antiviral agent suppressing hepatitis $\mathrm{C}$ virus in human hepatocytes. Hepatology 201154 1570-1579. (doi:10.1002/hep.24575)

22 Gascon-Barré M, Demers C, Mirshahi A, Néron S, Zalzal S \& Nanci A. The normal liver harbors the vitamin D nuclear receptor in nonparenchymal and biliary epithelial cells. Hepatology 2003 37 1034-1042. (doi:10.1053/jhep.2003.50176)
23 Diorio C, Bérubé S, Byrne C, Mâsse B, Hébert-Croteau N, Yaffe M, Coté G, Pollak M \& Brisson J. Influence of insulin-like growth factors on the strength of the relation of vitamin $\mathrm{D}$ and calcium intakes to mammographic breast density. Cancer Research 200666 588-597. (doi:10.1158/0008-5472.CAN-05-1959)

24 Heidegger I, Pircher A, Klocker H \& Massoner P. Targeting the insulin-like growth factor network in cancer therapy. Cancer Biology \& Therapy 201111 701-707. (doi:10.4161/cbt.11.8. 14689)

25 Gasco V, Prodam F, Grottoli S, Marzullo P, Longobardi S, Ghigo E \& Aimaretti G. Therapy of endocrine disease: $\mathrm{GH}$ therapy in adult GH deficiency: a review of treatment schedules and the evidence for low starting doses. European Journal of Endocrinology 2013168 R55-R66. (doi:10.1530/EJE-12-0563)

26 Molitch ME, Clemmons DR, Malozowski S, Merriam GR, Vance ML \& Endocrine Society. Evaluation and treatment of adult growth hormone deficiency: an Endocrine Society clinical practice guideline. Journal of Clinical Endocrinology and Metabolism 2011 96 1587-1609. (doi:10.1210/jc.2011-0179)

Received 22 June 2013

Revised version received 26 August 2013

Accepted 4 September 2013 